\title{
The Impact of the Expansion of the Bolsa Família Program on the Time Allocation of Youths and Their Parents
}

\author{
Lia Chitolina ${ }^{\dagger}$ \\ Miguel Nathan Foguel ${ }^{\ddagger}$ \\ Naercio Aquino Menezes-Filho ${ }^{\dagger, \S}$
}

\author{
Contents: 1. Introduction; 2. Description of the Bolsa Família program; 3. Literature review; 4. Data and \\ descriptive statistics; 5 . Identification strategy; 6. Results; 7. Final considerations. \\ Keywords: Bolsa Família, Youth, Education, Labor Supply. \\ JEL Code: $\quad 015$, D13, I38, J22.
}

This paper evaluates the impact of the expansion of the Bolsa Familia program to families with youths aged 16 to 17 years on the time allocation of youths and on the labor supply of their parents. A differences-in-differences intention to treat estimator was used to compare poor households with 16-year-old youths with households with 15-year-old adolescents before and after the expansion. The results show that granting the benefit had a positive and significant impact on school enrollment and on the decision of young people to study and work at the same time. The results evince that the impact seems to be absent in urban areas but it is quite high for youths living in rural areas. When the sample is stratified by region, positive effects were found on young people's school enrollment especially in the Northeast (in both urban and rural areas) and in the Southeast (only in the urban area). The econometric results also showed that the program hardly impacted the parents' labor supply decisions.

Este artigo avalia o impacto da expansão do programa Bolsa Família às famílias com jovens entre 16 a 17 anos sobre a alocação do tempo dos jovens e sobre a oferta de trabalho de seus pais. O estimador de diferenças-em-diferenças para o parâmetro intenção de tratar foi utilizado comparando as famílias pobres com jovens de 16 anos com famílias pobres com adolescentes de 15 anos de idade, antes e depois da expansão do programa. Os resultados mostram que a concessão do benefício

\footnotetext{
"We would like to express our gratitude to Fernando Botelho, Fabio Veras, the editor, and a referee for helpful comments. The paper has also benefited from comments received at the V Meeting of the Society for the Study of Economic Inequality (ECINEQ) in Bari, the 2013 IARIW-IBGE conference on income, wealth and well-being in Rio de Janeiro, and the XXXV Meeting of the Brazilian Econometric Society. The usual disclaimer applies.

†Universidade de São Paulo (USP).

${ }^{\ddagger}$ Instituto de Pesquisa Econômica Aplicada (IPEA).

§Insper. Rua Quatá, 300, Vila Olímpia, São Paulo, SP. CEP 04546-042. Email: naercioamf@insper.edu.br
} 
teve um impacto positivo e estatisticamente significativo sobre a frequência escolar e sobre a decisão dos jovens de estudar e trabalhar ao mesmo tempo. Os resultados indicam ausência de impacto nas áreas urbanas e efeito elevado para os jovens que vivem em áreas rurais. Estratificando a amostra regionalmente, impactos positivos foram encontrados para os jovens da região Nordestes (nas áreas urbana e rural) $e$ da região Sudeste (somente na área urbana). Os resultados também mostram que o programa praticamente não afetou a oferta de trabalho dos pais dos jovens.

\section{INTRODUCTION}

Conditional Cash Transfer (CCT) programs have been extensively used by many governments worldwide with the dual purpose of alleviating poverty in the short term and incrementing investment in human capital of children from poor families. The first goal is achieved via the money transfer component of programs, and the second by making the transfer conditional on beneficiary families meeting certain requirements such as pre-natal care, child immunization and school attendance of children and adolescents. It is expected that the children of beneficiary families acquire the necessary conditions to escape from poverty in the long term. ${ }^{1}$

However, the success of such programs in reducing poverty depends on how and to what extent the transfers and conditions of the programs impact the allocation of family time, particularly the time devoted to education and labor market activities. CCTs can affect the decisions on the labor supply of beneficiary family members in different directions, especially families with school age children. This is because a large set of factors such as family preferences and age composition, budget constraints, the magnitude of transfers, program's conditions, and the opportunity costs of attending school operate in a complex fashion so that one cannot predict a priori the direction of the effects of the intervention on the allocation of time devoted to education and work for children and labor market activities for adults. Indeed, CCTs are capable of triggering an income effect (via program's transfers) as well as substitution effects (via program's conditions and the opportunity costs of studying) whose final impact on the allocation of time within the household is not unambiguously predicted by theory. ${ }^{2}$ Unveiling the direction and magnitude of CCTs' impacts on the time use decisions within households is thus an empirical matter.

The key contribution of this study is an empirical assessment of the effects of the expansion of CCT programs on school enrollment and allocation of time in working and studying activities of beneficiary youths. We also assess whether the expansion impacted the labor supply (participation in the labor market and hours of work) of beneficiary adults. To accomplish that, we make use of the enlargement of the Brazilian Programa Bolsa Família (PBF) in 2007 to cover eligible families with children aged 16 and 17. More specifically, we exploit the creation of the Variable Benefit for Youngsters (Benefício Variável JovemBVJ), which is a variable benefit component of the PBF that provides cash transfers to and imposes school attendance conditions on eligible families who have youths with 16 or 17 years of age. ${ }^{3}$

As school dropout in Brazil increases significantly around age 15, the main purpose of introducing the BVJ was to stimulate youths at the targeted age bracket to stay longer in school. Since this is a critical age bracket for school dropouts of youths from poor families in many developing countries, we believe that our results can be useful both for countries that have already adopted CCTs but have not expanded them to this age bracket and for countries that are considering introducing a CTT as part of their short and long term strategy to reduce poverty.

\footnotetext{
${ }^{1}$ See Fiszbein et al. (2009) for an overall account of the rationale and the country experiences in the use of CCT programs.

${ }^{2}$ See e.g. Rubio-Codina (2010) for a model of the impacts of CTTs through income and own- and cross-substitution effects on the time allocation within the family across various types of activities (leisure, household chores, work, and education).

${ }^{3}$ In section 2, we present a detailed description of the eligibility rules of the PBF and its BVJ component.
} 
This study presents estimates of the impacts of the BVJ on youths' school attendance and labor market activity as well as on the labor market participation and working hours of their parents. Specifically, we look at the impacts of the program on school enrollment of youths as well as on their time allocation across four possible situations: only study, only work, study and work, and neither study nor work. Though we are not able to assess the BVJ's impact on the time dedicated to each of these activities, our results are capable to detect the effect of the program on these extensive margins. ${ }^{4}$

The effects of a CCT program can be heterogeneous in many different dimensions. For instance, they can differ between the genders of youths as well as between mothers and fathers. The youth position along the age structure of the household may also matter. Indeed, given that the BVJ's benefits are higher for older children and that there is a threat of losing the benefits if programs' rules are not respected, one could expect stronger effects on school enrollment for youths who are the youngest child in the family. Differences in access to schooling facilities and labor market opportunities may also lead to differential impacts between rural and urban areas. Similar reasoning applies to the Brazilian regions, which display quite different levels of development. We stratify our sample along these dimensions, to unveil the potential heterogeneities in our effects of interest.

The data we use are from the National Household Survey (Pesquisa Nacional por Amostra de DomicíliosPNAD), which is the main household survey in Brazil. Because PNAD does not identify which households receive PBF benefits, we focus on the poorest households to estimate the intention to treat parameter, which captures the potential impact of the program. Thus, households that are amongst the poorest 20 percent and have 16-year-old adolescents are included in the treatment group. The control group consists of households that are also part of the 20 percent poorest segment and have 15-year-old children. The effects are estimated using the differences-in-difference (DID) method with 2006 and 2009 being the pre- and post-program periods. In order to check the robustness of the results we conduct a placebo exercise using the same DID method for two years (2003 and 2006) before the program started. Results from this exercise indicate that the method seems appropriate for our purposes.

Our results show that the creation of the BVJ had an average effect of $1 \mathrm{pp}$ on the probability of school enrollment of the 16-year-olds from poor families in the country. The results also show that the increase in school enrollment for this group occurred mainly through the rise in the probability of studying and working (no statistically significant effects were found for the options of only studying, only working, or neither studying nor working). The school enrollment effect was substantially higher when the treated youths were the youngest child in the family (1 pp) and especially when the youngest were males (1 pp). Since the BVJ transfers may be suspended when families do not comply with the program's (education) requirement, this result provides indirect evidence of the power of the conditionality dimension of CCTs. An important finding of this study is that the impact of the BVJ was (statistically) absent in urban areas but substantial for rural families. Regarding parents' labor supply, we find that the program did not affect neither their labor market participation nor the average number of hours they work.

The paper is organized as follows. Section 2 describes the main features of the PBF and presents a historical evolution of the selection criteria and benefit amounts. In section 3, we present the related empirical evidence on the effects of CCT programs on education and labor supply outcomes. In section 4 , we describe the data and present descriptive statistics on relevant variables. Section 5 discusses the methodology used to measure the impact of the BVJ. The program's impacts on the outcomes of interest are presented in section 6 . This section also provides robustness tests for the main results. Section 7 contains our final considerations.

\footnotetext{
${ }^{4}$ For international results on the intensive margins, see Parker \& Skoufias (2000) and Rubio-Codina (2010). Both studies rely on a detailed household survey of time use to estimate the impacts of the Mexican CCT program (Oportunidades, formely named Progresa) on the time allocation of household members.
} 


\section{DESCRIPTION OF THE BOLSA FAMÍLIA PROGRAM}

The Bolsa Família program (PBF) is a large-scale CCT intervention that was implemented in 2004 with the aim of promoting immediate poverty alleviation and reducing the intergenerational transmission of poverty. ${ }^{5}$ The program was initially built through the unification of other social programs, both conditional and unconditional, such as School Allowance (Bolsa Escola), Food Allowance (Bolsa Alimentação), Food Card (Cartão-Alimentação) and Gas Aid (Auxílio Gás).

The PBF benefits families in poverty or extreme poverty throughout Brazil and is based on three main axes: cash transfer, conditions and complementary programs. Beneficiary families are selected from information collected for the Unified Registry for Social Programs (Cadastro Único para Programas SociaisCADUNICO) but registration in CADUNICO does not imply automatic entry into the program. ${ }^{6}$ The main criterion for selection is the family's per capita income and the program's transfers are preferably paid to women through a debit card.

The PBF eligibility criteria when the BVJ was launched in 2007 classified as "extremely poor" families whose per capita monthly income was up to R\$60 (around US\$30), regardless of family composition, and as "poor" those families whose per capita monthly income was between R\$60 and R\$120 (US\$60). To be eligible, the second group of families must include pregnant women, nursing mothers or children and adolescents up to 17 years old. Families in extreme poverty are entitled to the Basic Benefit (Beneficio Básico) regardless of family composition. There are two main variable benefits which are granted to both the extremely poor and poor households:

(i) the Variable Benefit (Beneficio Variável), which is paid to families that have children up to 15 years of age or pregnant or nursing mothers, and

(ii) the Variable Benefit for Youngsters (Bolsa Variável Jovem-BVJ), which is paid to families with youths aged 16 or $17 .^{7}$

Each family can receive up to five Variable Benefits and up to two BVJs. Benefits are paid on a monthly basis. The historical evolution of the program's benefits and eligibility criteria during the period of our analysis are shown in Table 1.

The transfer of the two main variable benefits of the program is conditioned on health and education requirements. Health conditions require children younger than 7 years old to have their growth monitored and vaccinations up-to-date and pregnant and nursing women to visit regularly health centers for prenatal and postnatal care. Education conditions are that all children aged 6 to 15 must be enrolled in school and attend at least $85 \%$ of school days. Enrollment in school is also required for youths aged 16 and 17 and the minimum attendance rate for them is 75 percent. Variable benefits are paid until December of the year when the child becomes 15 years old or when the youth completes 17 years old. After its inception in 2007, when a child becomes 16 the family is entitled to receive the higher benefit of the BVJ.

\footnotetext{
${ }^{5}$ Although the conception of the program began in 2003, it was only officially enacted by Law No. 10,836 in January 2004 . The program has been managed by the Ministry of Social Development and Fight against Hunger (Ministério do Desenvolvimento Social e Combate à Fome-MDS) since its inception.

${ }^{6}$ The Unified Registry is maintained by the federal government and the primary information about the families is collected by municipal authorities.

${ }^{7}$ Additionally, there are two other forms of benefits:

(i) the Extraordinary Variable Benefit (Beneficio de Caráter Extraordinário) is an amount calculated on a case-by-case basis which is paid to families in the Gas Aid, School Allowance, Food Allowance and Food Card programs, whose migration to the PBF caused financial loss; and

(ii) the Benefit for Overcoming Extreme Poverty in Early Childhood (Beneficio para Superação da Extrema Pobreza na Primeira Infância) is an amount paid to beneficiary families with children aged 0 to 6 so that the per capita family income reaches the extreme poverty line. The first benefit exists since the outset of PBF, whereas the second since 2012.
} 
Table 1. Evolution of the eligibility criteria and benefits of the PBF (RS).

\begin{tabular}{llcccccc}
\hline & 2004 & 2005 & 2006 & 2007 & 2008 & 2009 \\
\hline$(1)$ & Extremely Poor & 50 & 50 & 60 & 60 & 60 & 70 \\
$(2)$ & Poor & 100 & 100 & 120 & 120 & 120 & 140 \\
$(3)$ & Basic Benefit & 50 & 50 & 50 & 58 & 62 & 68 \\
$(4)$ & Variable Benefit & 15 & 15 & 15 & 18 & 20 & 22 \\
$(5)$ & Variable Benefit for Youngsters & 0 & 0 & 0 & 0 & 33 & 33 \\
\hline
\end{tabular}

Notes: Rows (1) and (2) show the eligibility criteria for receiving Bolsa Familia Transfers. Rows (3), (4) and (5) show value of transfers. The extremely poor families receive the basic benefit independently of the number of children. The poor families only receive the variable benefits and in the case they have children. Data from the Ministry of Social Development (Ministério do Desenvolvimento Social e Combate à Fome-MDS).

As long as eligible, families can stay in the program with recertification every two years. Verification of conditions is the responsibility of the federal government with the help of municipal authorities. Noncompliance with the conditions generates progressive sanctions which start with a simple warning, goes through a suspension of the benefits for one or two months and end up with the total suspension of the benefits. ${ }^{8}$

In terms of coverage, the PBF is granted to more than 13 million household and is currently one of the major instruments of social policy in Brazil. ${ }^{9}$ In budgetary terms the PBF is relatively small and accounts for approximately 0.5 percent of Brazilian GDP.

\section{LITERATURE REVIEW}

This section presents international as well as Brazilian evidence on the effects of CCTs on education and labor supply outcomes. As we are interested in the effects of the expansion of the PBF on youths aged 16 and 17, our focus will be on the education and labor supply effects for this group. We also cover the evidence on the labor supply effects on adults.

\subsection{Effects on education}

Using the randomized experiment of the Mexican CCT (Progresa, named Oportunidades after 2001), Skoufias, Parker, Behrman, \& Pessino (2001) shows that the school enrollment rate for boys aged 16 and 17 years old increases by 5.4 percentage points ( 20 percent in relative terms) but does not find evidence of impact for girls in the same age group. Combining structural modeling with the randomized feature of Progresa, Attanasio, Meguir, \& Santiago (2012) estimates a positive impact of the program on school enrollment of boys, particularly after primary school. ${ }^{10}$ Rubio-Codina (2010) estimates a positive impact on schooling and a negative impact on labor market work of Oportunidades for teenage (12 to 17 year-olds) boys and girls. Behrman, Gallardo-García, Parker, Todd, \& Vélez-Grajales (2012) estimates the

\footnotetext{
${ }^{8}$ Brollo, La Ferrara, \& Kaufmann (2015) show that this system detected that around 7 percent of beneficiary families failed to comply with the school attendance requirements between July 2008 and November 2009. Brollo, La Ferrara, \& Kaufmann (2013) show evidence that the adjustments in compliance behavior of beneficiary families occurs not only via their own experiences of warnings and punishments given by the system but also from the experiences of peer families. The available literature provides no evidence on whether the compliance behavior of families differs according to the age of the child.

${ }^{9}$ According to Soares \& Satyro (2009), the PBF beneficiaries are outnumbered only by those of the Unified Health System (Sistema Único de Saúde-SUS), which in theory covers the entire Brazilian population; the public education system, which covers 52 million students; and the Social Security system, which grants 21 million benefits.

${ }^{10}$ One interesting aspect of Attanasio et al. (2012) is that it calls attention for the importance of taking the differences in the local labor market wages into the analysis. In our main regression on school enrollment, we include the average wage of youths in the state where he/she lives as a control variable.
} 
effects of the expansion of Oportunidades into urban areas and finds positive and statistically significant impacts of the program on schooling attainment for both boys and girls aged 15 to 18 but no effects on market work for this age group.

For the Familias en Accion program in Colombia, Attanasio, Fitzsimons, \& Gomez (2005) finds a positive impact on school enrollment of 14- to 17-years-olds of around 6 percentage points both in urban and rural areas (8 and 11 percent in relative terms in each area respectively). Schady, Araujo, Peña, \& López-Calva (2008) study the effects of the Bono de Desarrollo Humano in Ecuador on the school enrollment of the group of children 6 to 17 years old. They estimate an impact of around 10 percentage points for the whole group and, when considering heterogeneous effects by the highest grade completed, the estimated effect becomes approximately 13 percentage points for those who completed the ninth grade.

Exploiting the varying times at which the Female Secondary School Assistance Project was implemented across the districts of Bangladesh, Khandker, Pitt, \& Fuwa (2003) estimates an impact of 12 percentage points (27 percent in relative terms) on secondary school enrollment of girls aged 11 to 18 years for each year of exposure to the program. In Turkey, the effect of the Social Risk Mitigation Project was investigated by Ahmed et al. (2007), who reports an effect of 11 percentage points on the secondary school enrollment of girls 14-17 years old in the whole country. The impact in rural areas is much higher reaching 17 percentage points among children in this age bracket.

For Brazil, Costanzi, Souza, \& Ribeiro (2010) estimates a positive effect of the PBF (including the BVJ) on school enrollment for children between 7 and 17 years old. Pellegrina (2011) also unveils positive effects of the PBF for students in São Paulo on variables that were directly tied to program conditions, such as enrollment and absence rates. De Janvry, Finan, \& Sadoulet (2007) uses data collected in the Northeast of Brazil to estimate the effect of the Bolsa Escola (School Allowance) program, a precursor of the PBF. Their results evince that the program reduces drop-out rates by approximately 8 percent in both primary and secondary school levels but has little effect on failure rates. Also evaluating the Bolsa Escola intervention, Bourguignon, Ferreira, \& Leite (2003) uses ex-ante simulation methods and also finds a decrease in drop-out rates. Glewwe \& Kassouf (2012) uses panel data at the school level from 1998 to 2005 to evaluate the effects of the Bolsa Escola/Bolsa Família programs and finds a positive impact on school enrollment, a negative impact on drop-out and a positive effect on grade promotion.

\subsection{Effects on labor supply}

Skoufias et al. (2001) finds evidence that Progresa reduces the labor force participation of children aged 12 to 17 , both for boys and for girls. Nevertheless, focusing on the 16-17 year-old subgroup, the estimated effect is negative ( -5.2 and -2.0 percentage points for boys and girls respectively) but not statistically significant at conventional levels. Skoufias \& Di Maro (2008) finds no significant effect of Progresa on adults' labor supply, in particular with respect to participation in the labor market. Attanasio et al. (2005) finds no effect of the Colombian Familias en Acción program on child work but provides evidence that children partially substitute work for school, with this substitution effect being higher for children aged 14 to 17 in urban areas. Edmonds \& Schady (2009) shows evidence that the beneficiary families of Bono de Desarrollo Humano in Ecuador delay the entry of the child into paid employment. The study also shows evidence of a large decline in child work, in particular for those that are most vulnerable to transitioning from school to work. Alzúa, Cruces, \& Ripani (2010) estimates the effects on the labor market of three CCTs: the Mexican Progresa/Oportunidades, the Nicaraguan Red de Protección Social-RPS (Social Protection Network), and the Programa de Asignación Familiar-PRAF (Family Allowance Program) implemented in Honduras. The empirical results indicate that none of the three programs leads to significant changes in adults' participation in the labor force.

As for the effects of the PBF on labor supply, Pedrozo Jr (2010) finds a negative impact on adults' labor supply, especially that of single or divorced mothers. The author also presents evidence that children's participation in the labor market is not affected by the program. Tavares (2010) shows that mothers receiving the PBF experienced a 5.6 percent increase in the probability of participating in the labor 
market and extended their weekly working hours by 1.6 percent. The study also shows that higher benefits are associated with a lower probability of participation and a lower level of weekly working hours. In a similar study, Ferro \& Nicolella (2007) finds that participation in the PBF does not affect the probability that parents participate in the labor force. They also evince that the program leads to changes in working hours, with the effect being positive for mothers in urban areas and negative for mothers in rural areas and fathers in urban areas. Further, the study presents evidence that the program is more effective in reducing female child labor as compared to male child labor. Medeiros, Britto, \& Soares (2007) computes the impact of the PBF at different deciles of the income distribution and shows that the labor market participation rate of beneficiary households is somewhat higher than that of nonbeneficiary households in the first three deciles of the distribution. Taking into account the amount of the benefit relative to household income and demographic composition, Teixeira (2008) finds a reduction in the number of weekly working hours of adults that varies between 0 and 3.5 hours. Foguel \& Barros (2010) finds that the impact of the PBF on female labor market participation is not significant either on statistical grounds or in terms of magnitude. As for males, they find evidence that the program's effect on the rate of participation is positive, though very small in magnitude. In terms of the supply of hours, their results indicate a small negative effect for females but no impact for males is detected.

\section{DATA AND DESCRIPTIVE STATISTICS}

The data used in the empirical analysis were drawn from the National Household Survey(Pesquisa Nacional por Amostra de Domicílios-PNAD), an annual survey conducted by the Brazilian Institute of Geography and Statistics (Instituto Brasileiro de Geografia e Estatística-IBGE). PNAD is a cross-section survey that provides information on the demographic and socio-economic features of around 100 thousands households in whole country. We use the versions of PNAD for 2001, 2004, 2006 and 2009, with the last two years serving as the pre- and post-treatment periods in the estimation of the effect of the BVJ program.

To justify the use in the analysis of households among the poorest 20 percent, Table 2 shows the distribution of PBF beneficiaries across the deciles of the per capita family income distribution as well as the proportion of the program's beneficiaries within each decile. The information is based on the supplementary questionnaire that is available in version of PNAD in 2004. ${ }^{11}$ The results show that more than 50 percent of beneficiary households were in the two poorest deciles of the income distribution and that more than 40 percent of households in these two deciles were recipients of the program. These figures thus evince that the two poorest deciles represent a good group of the population for capturing the (intention-to-treat) effect of interest.

A descriptive analysis of the data was performed to make a preliminary assessment of the effects of the PBF on the participation in the labor force of youths and other household members. For the analyses that follow, the treatment group comprises families with 16-year-olds that were among the poorest 20 percent according to per capita family income. The fact that 15 -year-olds were not affected by the policy change allows us to construct a possible comparison group. Thus, the control group comprises families with 15-year-olds that were among the poorest 20 percent of the population. It is important to note that we excluded from the sample all households with adolescents of both 15 and 16 years of age, because these households would be in both the treatment and control groups, and the effect of the program on one youngster could affect the behavior of the other.

Table 3 shows a series of descriptive statistics for households that were in the treatment and control groups in 2006, the year preceding the introduction of the BVJ.

As expected, the treatment and control groups were akin in many different characteristics. Regarding household composition, on average, both groups had similar number of household members and children. There is also no relevant difference in the average amount of "other income", a category that

\footnotetext{
${ }^{11}$ The PNAD does not usually provide exact information about which households receive the PBF or any other social program.
} 
Table 2. Share of beneficiary families by decile 2004 .

\begin{tabular}{lcc}
\hline $\begin{array}{l}\text { Deciles of Family } \\
\text { Income Distribution }\end{array}$ & $\begin{array}{c}\text { Distribution } \\
\text { Across the Deciles }\end{array}$ & $\begin{array}{c}\text { Proportion } \\
\text { Within the Deciles }\end{array}$ \\
\hline 1 (poorest) & 26.0 & 43.2 \\
2 & 24.4 & 41.5 \\
3 & 19.5 & 29.5 \\
4 & 12.9 & 25.4 \\
5 & 8.5 & 15.1 \\
6 & 4.4 & 6.7 \\
7 & 2.5 & 4.2 \\
8 & 1.1 & 1.8 \\
9 & 0.5 & 0.7 \\
10 (richest) & 0.3 & 0.4 \\
\hline Total & 100.0 & - \\
\hline
\end{tabular}

Notes: Entries show the shares of all Bolsa Familia beneficiaries across and within the deciles of per capita household income distribution. Data from PNAD 2004.

captures income received from saving accounts, dividends, and transfers. Around 2/3 of the control group lived in urban areas and the treatment group was slightly less urbanized. The age of the head of the household was higher in households with 16-year-olds. As might be expected, the age of the eldest (youngest) offspring was higher (lower) among households with 16(15)-year-olds. For these three variables associated with age, the differences between the groups were significant at the 1 percent level.

Regarding individual traits, on average, both mothers and fathers in the control group had slightly more years of schooling than the parents in the treatment group. Mothers and fathers from the control group were a little older than their counterparts in the treatment group. Regarding the labor market variables, there was no statistical difference between the two groups for mothers' or fathers' labor supply and wage variables. In both the treatment and control groups, over 60 percent of mothers and over 90 percent of fathers were employed. On average, fathers worked more hours than mothers and commanded a higher wage.

Concerning the characteristics of children in the two groups, the education level was on average half a year higher for the children in the treatment (6.1 years of schooling) than in the control (5.6) group. The employment rate was also higher for the former group ( 41 percent) than for the latter ( 33 percent) with the same pattern observed for weekly working hours ( 26.2 vs. 23.7 , respectively). While these higher figures for the treatment group were significant at the 1 percent level, the higher average wage was only weakly significant on statistical grounds. Given that the households in the treatment group have 16 year-olds and no 15 year-olds and that the households in the control group are in the opposite case, these marginal differences are not surprising.

\section{IDENTIFICATION STRATEGY}

The effect of receiving the BVJ benefit on school attendance and labor supply was estimated through the method of differences-in-difference (DID). This method compares two groups, one of which was affected by a particular policy change (the treatment group) while the other (the control group) is not exposed to the policy change. The usual way to estimate a linear DID model including covariates is:

$$
Y_{i t}=\beta_{0}+\beta_{1} \text { Treat }_{i}+\beta_{2} \text { After }_{t}+\beta_{3}\left(\text { Treat }_{i} \times \text { After }_{t}\right)+\beta_{4}^{\prime} X_{i t}+\varepsilon_{i t},
$$


Table 3. Descriptive statistics - treatment and control groups - 2006

\begin{tabular}{|c|c|c|c|}
\hline & $\begin{array}{c}15 \text { years-old } \\
\text { (Control Group) }\end{array}$ & $\begin{array}{c}\text { 16-years-old } \\
\text { (Treatment Group) }\end{array}$ & Difference \\
\hline \multicolumn{4}{|l|}{ Household } \\
\hline Household size & $\begin{array}{c}5.70 \\
(1.96)\end{array}$ & $\begin{array}{c}5.57 \\
(1.95)\end{array}$ & $0.13^{*}$ \\
\hline Number of children & $\begin{array}{c}3.76 \\
(1.84)\end{array}$ & $\begin{array}{c}3.61 \\
(1.81)\end{array}$ & $0.14^{* *}$ \\
\hline Age of the head of household & $\begin{array}{l}43.68 \\
(8.34)\end{array}$ & $\begin{array}{l}44.82 \\
(8.15)\end{array}$ & $-1.14^{* * *}$ \\
\hline Age of the youngest child & $\begin{array}{c}9.13 \\
(4.68)\end{array}$ & $\begin{array}{c}9.85 \\
(4.89)\end{array}$ & $-0.72^{* * *}$ \\
\hline Age of the oldest child & $\begin{array}{l}17.32 \\
(3.28)\end{array}$ & $\begin{array}{l}18.34 \\
(3.63)\end{array}$ & $-1.02^{* * *}$ \\
\hline Urban & $\begin{array}{c}0.65 \\
(0.48)\end{array}$ & $\begin{array}{c}0.62 \\
(0.48)\end{array}$ & 0.03 \\
\hline Other income & $\begin{array}{c}87.82 \\
(67.12)\end{array}$ & $\begin{array}{l}88.40 \\
(66.57)\end{array}$ & -0.58 \\
\hline \multicolumn{4}{|l|}{ Individuals } \\
\hline \multicolumn{4}{|l|}{ Mother } \\
\hline Age & $\begin{array}{l}40.26 \\
(6.75)\end{array}$ & $\begin{array}{l}41.58 \\
(6.90)\end{array}$ & $-1.31^{* * *}$ \\
\hline Educational level & $\begin{array}{c}3.68 \\
(3.27)\end{array}$ & $\begin{array}{c}3.48 \\
(3.22)\end{array}$ & 0.20 \\
\hline Employment & $\begin{array}{c}0.65 \\
(0.48)\end{array}$ & $\begin{array}{c}0.62 \\
(0.14)\end{array}$ & 0.02 \\
\hline Weekly working hours & $\begin{array}{l}27.13 \\
(16.57)\end{array}$ & $\begin{array}{c}27.49 \\
(16.45)\end{array}$ & -0.35 \\
\hline Wage from main job & $\begin{array}{c}187.77 \\
(128.48)\end{array}$ & $\begin{array}{c}189.07 \\
(129.03)\end{array}$ & -1.28 \\
\hline \multicolumn{4}{|l|}{ Father } \\
\hline Age & $\begin{array}{l}44.26 \\
(8.77)\end{array}$ & $\begin{array}{l}45.76 \\
(8.40)\end{array}$ & $-1.49^{* * *}$ \\
\hline Educational level & $\begin{array}{c}3.09 \\
(3.21)\end{array}$ & $\begin{array}{c}2.87 \\
(3.16)\end{array}$ & 0.22 \\
\hline Employment & $\begin{array}{c}0.93 \\
(0.25)\end{array}$ & $\begin{array}{c}0.91 \\
(0.28)\end{array}$ & 0.02 \\
\hline Weekly working hours & $\begin{array}{c}44.42 \\
(12.70)\end{array}$ & $\begin{array}{c}43.72 \\
(12.57)\end{array}$ & 0.70 \\
\hline Wage from main job & $\begin{array}{c}286.19 \\
(152.75)\end{array}$ & $\begin{array}{c}293.54 \\
(154.65)\end{array}$ & -7.35 \\
\hline \multicolumn{4}{|l|}{ Childrens } \\
\hline Educational level & $\begin{array}{c}5.64 \\
(2.01)\end{array}$ & $\begin{array}{c}6.14 \\
(2.27)\end{array}$ & $-0.50^{* * *}$ \\
\hline Employment & $\begin{array}{c}0.33 \\
(0.47)\end{array}$ & $\begin{array}{c}0.41 \\
(0.49)\end{array}$ & $-0.08^{* * *}$ \\
\hline Weekly working hours & $\begin{array}{c}23.73 \\
(13.76)\end{array}$ & $\begin{array}{l}26.18 \\
(13.48)\end{array}$ & $-2.45^{* * *}$ \\
\hline Wage from main job & $\begin{array}{l}96.23 \\
(67.55)\end{array}$ & $\begin{array}{l}111.12 \\
(77.55)\end{array}$ & $-14.90^{*}$ \\
\hline
\end{tabular}

Notes: Sample of households among the poorest 20 percent in 2006 with children aged 15 and 16 years only. Standard deviation in parentheses. Stars reflect statistical significance at the ${ }^{* * *} 1$ percent, ${ }^{*} 5$ percent, and ${ }^{*} 10$ percent levels. 
in which $Y_{i t}$ is the outcome of interest; Treat ${ }_{i}$ is an indicator that takes on value 1 if individual $i$ is in the treatment group and 0 otherwise; After ${ }_{t}$ is dummy variable that equals 1 for post-intervention periods and 0 otherwise; $X_{i t}$ represents a vector of control variables for possible systematic differences across individuals in the treatment and control groups; and the term $\varepsilon_{i t}$ absorbs unobserved components that affect the dependent variable. In this model, $\beta_{1}$ measures the group effect before the policy change, $\beta_{2}$ measures the time effect of aggregate factors that affect $Y$ even in the absence of the policy change, and $\beta_{3}$, which captures changes in $Y$ for the treatment group after treatment, is the DID estimator.

It is important to stress that this identification procedure allows capturing only the "intention to treat" (ITT) effect of the BVJ for households in the bottom quantile of the income distribution. As we do not observe whether or not the households actually receive the transfer, we estimate the impact of being entitled to receive it on school attendance and time allocation. To the extent that a significant share of households that have become entitled to the transfer do not actually apply for it, we may be underestimating the impacts of the program.

Taking conditional expectations of equation (1) for each group and time period, we can obtain the usual double difference of the DID model:

$$
\begin{aligned}
\mathbf{E}\left[Y_{i 1}-Y_{i 0} \mid X_{i t}, \text { Treat }_{i}=1\right] & -\mathbf{E}\left[Y_{i 1}-Y_{i 0} \mid X_{i t}, \text { Treat }_{i}=0\right] \\
& =\beta_{3}+\left\{\mathbf{E}\left[\varepsilon_{i 1}-\varepsilon_{i 0} \mid X_{i t}, \text { Treat }_{i}=1\right]-\mathbf{E}\left[\varepsilon_{i 1}-\varepsilon_{i 0} \mid X_{i t}, \text { Treat }_{i}=0\right]\right\},
\end{aligned}
$$

where the subscripts 0 and 1 represent the pre- and post-treatment periods. Expression (2) shows that the DID identifies the effect of the treatment on $Y$ if the term in brackets on the right-hand side is nil. This corresponds to the main assumption of the DID model and is usually known as the equal trend assumption.

Looking at figures for school attendance of the treatment and control groups, Figure 1 shows that the trends were similar for the two groups between 2001 and 2006. Table 4 provides a more formal test of this visual result. Indeed, it shows that coefficient on the interaction between the treatment dummy (i.e., Treat ${ }_{i}$ ) and a linear trend is not only small in magnitude but also statistically insignificant. This pattern is observed for the whole sample as well as when the urban and rural areas are taken separately.

Figure 1. Pre-Trends: school attendance before treatment.

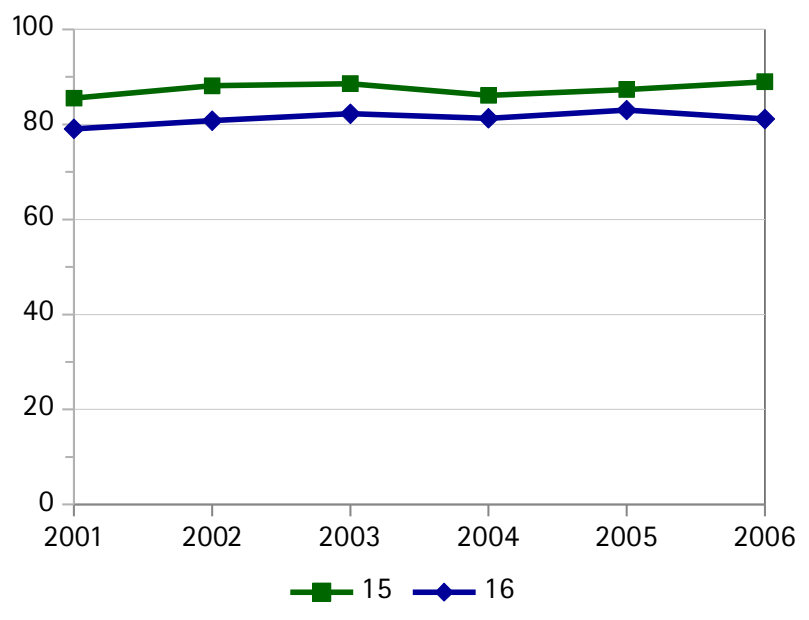


Table 4. Pre-program School Attendance - 2001-2006.

\begin{tabular}{lccc}
\hline Variables & All & Urban & Rural \\
\hline Trend & 0.003 & 0.003 & 0.003 \\
& $(0.002)$ & $(0.002)$ & $(0.004)$ \\
Treated & $-0.067^{* * *}$ & $-0.071^{* * *}$ & $-0.060^{* * *}$ \\
& $(0.013)$ & $(0.016)$ & $(0.022)$ \\
Trend $\times$ Treated & 0.002 & 0.003 & 0.000 \\
& $(0.003)$ & $(0.004)$ & $(0.006)$ \\
Constant & $0.864^{* * *}$ & $0.874^{* * *}$ & $0.843^{* * *}$ \\
& $(0.008)$ & $(0.010)$ & $(0.014)$ \\
\hline Observations & 18,268 & 11,868 & 6,400 \\
R-squared & 0.007 & 0.008 & 0.006 \\
\hline
\end{tabular}

Notes: Sample of households among the poorest 20 percent between 2001 and 2006 with children aged 15 and 16 years only. Standard deviation in parentheses. Stars reflect statistical significance at the ${ }^{* * *} 1$ percent, ${ }^{* *} 5$ percent, and ${ }^{*} 10$ percent levels.

\section{RESULTS}

\subsection{Impact on adolescents}

The impact of the BVJ on the youngster's school enrollment was estimated using equation (1) of section 5. Specifically, the DID model used to estimate the effect of the BVJ has the following form:

$$
Y_{i t}=\beta_{0}+\beta_{1} \text { Treat }_{i}+\beta_{2} 2009+\beta_{3} \text { Treat }_{i} * 2009+\beta_{4} X_{i t}+\varepsilon_{i t},
$$

where $i$ represents the individual and $t$ is time; $Y_{i t}$ is the dependent variable of interest (school enrollment or participation in the labor market); Treat $_{i}$ is the indicator for the treatment group (households with an adolescent aged 16); 2009 is the indicator for the second period (the first period is 2006); $X_{i t}$ represents the vector of control variables and $\varepsilon_{i t}$ comprises random shocks. The controls include the number of children in the household, the education level of the mother or father (whichever is greater), the age of the mother or father (whichever is greater), household composition, race and indicators for urban areas and state of residence. We also included the average market wages of youths aged 15 and 16 (differentiated by gender) at the state level to take into account that school enrollment for youths in poor families can be particularly affected by their opportunity costs in the labor market. As the availability of schools and the labor market opportunities for youngsters are different in urban and rural areas, the regression was separately run for these areas.

Table 5 shows the results of estimating equation (3) to obtain the effect of the introduction of BVJ on school enrollment. The first two columns contains the results for the whole sample while the third and fourth for the urban and rural areas respectively. The table shows that the estimated effect of the interaction between treatment and time is positive and significant at the 1 percent level, regardless of whether the control variables are included (column (1)) or not (column (2)). The estimated effects evinces that the expansion of the PBF for young people of 16 years of age increased the probability attending school by approximately 5 percentage points with respect to 15 -year-olds. This result is noteworthy because, in addition to the immediate relief of poverty, one of the main purposes of the PBF is to reduce the transmission of poverty in the medium and long terms by increasing school enrollment among the poorest households. The results suggest that the expansion of the PBF to 16-year-olds has contributed to that goal. 
Table 5. Impact of BVJ on school attendance.

\begin{tabular}{lcccc}
\hline Variables & $(1)$ & $(2)$ & $(3)$ & $(3)$ \\
& & & Urban & Rural \\
\hline Treated & $-0.080^{* * *}$ & $-0.073^{* * *}$ & $-0.065^{* * *}$ & $-0.090^{* * *}$ \\
& $(0.015)$ & $(0.015)$ & $(0.018)$ & $(0.026)$ \\
2009 & $0.031^{* * *}$ & $0.036^{* * *}$ & $0.042^{* * *}$ & 0.015 \\
& $(0.012)$ & $(0.015)$ & $(0.018)$ & $(0.029)$ \\
Treated*2009 & $0.049^{* * *}$ & $0.047^{* * *}$ & 0.029 & $0.090^{* * *}$ \\
& $(0.019)$ & $(0.019)$ & $(0.022)$ & $(0.033)$ \\
Market Wages & - & $-0.041^{* *}$ & $-0.051^{* *}$ & 0.008 \\
& & $(0.021)$ & $(0.024)$ & $(0.045)$ \\
Constant & $0.890^{* * *}$ & $1.035^{* * *}$ & $1.069^{* * *}$ & $0.884^{* * *}$ \\
& $(0.009)$ & $(0.066)$ & $(0.077)$ & $(0.140)$ \\
\hline Observations & 4,781 & 4,781 & 3,193 & 1,588 \\
R-squared & 0.015 & 0.052 & 0.058 & 0.058 \\
\hline
\end{tabular}

Notes: Dependent variable is a binary indicator of school attendance. Sample includes households among the poorest 20 percent with children aged 15 and 16 years only. Robust standard errors in parentheses. Column (2), (3), and (4) include controls for number of children, education, age and race of head, household composition, urban areas (only column (2)), and state dummies. Standard deviation in parentheses. Stars reflect statistical significance at the ${ }^{* * *} 1$ percent, ${ }^{* *} 5$ percent, and ${ }^{*} 10$ percent levels.

Figure 2 compares the average rates of school attendance in the bottom and in the top quintiles of the family income distribution. We can note that at age 16 there is a difference of about 16 percentage points between these two groups ( $80 \%$ versus $96 \%$ ). Thus, the magnitude of the estimated effect means that BVJ has contributed to reduce this difference by almost one third.

When the sample is stratified between urban and rural areas, the results evince that the effect of the BVJ was quite high and statistically significant in the rural area and not different from zero on statistical grounds in the urban area. In section 3.1, we reported that the international literature has typically found positive effects for both areas, so while ours results are line for the rural area, it is not for the urban sphere. This could be explained by the distinct program designs and forms of operation, by the different samples and controls or by the fact that most studies in the literature do not estimate the intention to treat parameter, as we do here. In spite of these differences, we find it interesting to unveil that the extension of the PBF to youngsters in Brazil seems to have mainly affected their school enrollment in rural localities. Among the reasons for that, it is likely that the lower (higher) enrollment rates for youths in rural (urban) areas and the higher (lower) relative importance of the benefits of the BVJ to rural (urban) families explain part of the observed difference in estimated impacts. It is interesting to note that the market wage for youths does not affect school enrollment in the rural area but has the expected negative sign for urban youngsters.

We also estimate a multinomial logit model to gauge the impact of the program on the young people's labor supply and school enrollment decisions. In this formulation, the dependent variable consists of four categories: "studying only", "working only", "studying and working", and "neither studying nor working", with the last being considered the baseline category in the estimation.

As the multinomial model is non-linear, the marginal effect of the treatment in a DID model is not the marginal impact of the interaction between time and treatment, but the difference of the cross- 
Figure 2. School attendance by age in bottom and top quintiles.

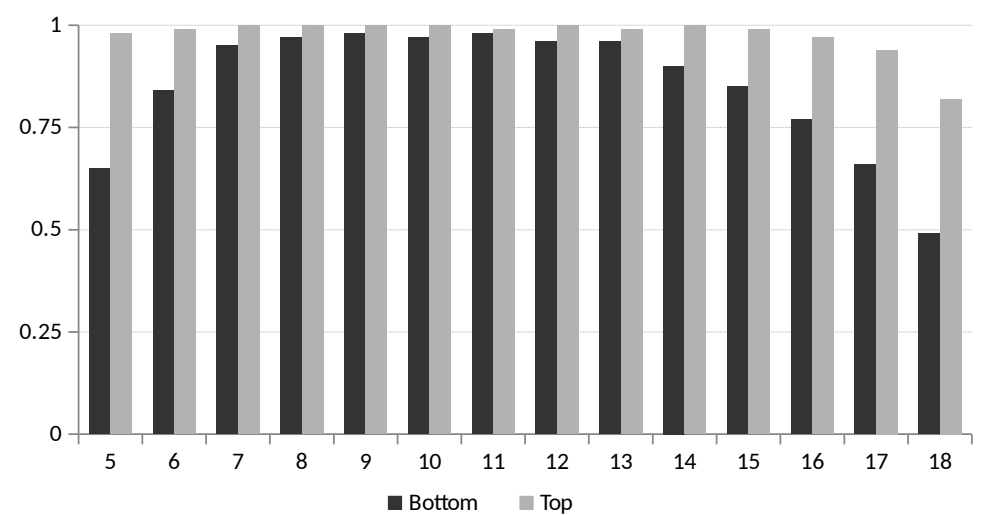

differences, as described by Puhani (2012). The results of Table 6 (in terms of marginal effects) show that the BVJ has a significant effect on the probability studying and working at the same time, but not on the other outcome variables. The estimated marginal effect means that the probability of a youngster studying and working increases by 4.4 percentage points with the BVJ, compared with a baseline of $30 \%$ in the control group in 2006. The estimated coefficients for the categories were not statistically significant. It seems, therefore, that treated adolescents do not quit their jobs to study because of the program, but do both activities at the same time. This raises questions about the long run impacts of the program, since the quality of the night classes is notoriously low in Brazil. We ran the same multinomial model stratifying the sample between the urban and rural areas. The results show the same pattern for rural youths but, as previously found for school enrollment, it seems that the BVJ was not able to

Table 6. Impact of the BVJ on time allocation.

\begin{tabular}{lccc}
\hline Variables & All & Urban & Rural \\
\hline Not Studying nor Working & -0.038 & -0.028 & -0.086 \\
& $(0.025)$ & $(0.029)$ & $(0.059)$ \\
Studying Only & 0.004 & 0.012 & -0.020 \\
& $(0.013)$ & $(0.010)$ & $(0.040)$ \\
Working Only & -0.010 & -0.009 & 0.008 \\
& $(0.029)$ & $(0.034)$ & $(0.055)$ \\
Studying and Working & $0.044^{* *}$ & 0.026 & $0.097^{* *}$ \\
& $(0.022)$ & $(0.025)$ & $(0.048)$ \\
\hline Observations & 4,781 & 3,193 & 1,588 \\
\hline
\end{tabular}

Notes: The dependent variable is time allocation (the four options in the first column). Sample includes households among the poorest 20 percent with children aged 15 and 16 years only. Robust standard errors in parentheses. Entries are marginal effects of each variable on the predicted probability of each option. Columns report results of a single (multinomial logit) regression and include controls for number of children, education, age and race of head, household composition, urban areas (only the "All" sample), and state dummies. Starred coefficients are significant at the ${ }^{* * *} 1$ percent, ${ }^{* *} 5$ percent, and *10 percent levels. 
change the allocation of the work-study activities for the youths in urban areas.

The effects of the expansion of the PBF may also be heterogeneous with respect to the characteristics of the beneficiaries. We examined this possibility by splitting the sample of youngsters by gender and by considering only those who were the youngest child in the household in which they resided, for both the treatment and the control groups. According to the results reported in Table 7, the probability of attending school increased for young males as a result of the program, while for young females the effect was not statistically significant. In the cases where the beneficiaries were the youngest child in the household, the program caused an increase of around 10 percentage points in the probability of attending school. One possible reason for this substantial increase in the impact is that the family only receives any transfer from the Bolsa Familia program because the youngest child in the family is attending school. In other words, the fear of losing access to the program may stimulate parents to enroll their kids' in school and monitor their attendance more strongly. When these two features are combined-i.e., male youngsters who were the youngest child — the probability of attending school increases to 15 percentage points and it is statistically significant at the 1 percent level.

Contrasting the results for urban and rural areas, we see again that the BVJ does not seem have stimulated an increase in school enrollment in the former area but had a substantial impact on rural youths. The pattern of impacts is similar to what was observed in the overall sample: positive impact for boys but not for girls and a large effect for the youngest child in the household, especially if it was a boy.

We use the same procedure to check whether the impacts of BVJ on the adolescents' time allocation were also different by gender and the children's age composition within the household. The results of Table 8 show that this is indeed the case. The impact of BVJ on the probability of studying and working at the same time appears for girls but it is strong for boys when they were the youngest child in the family. It is noteworthy that the impact of the intervention seems to have only altered probability of combining the activities of working and studying.

Table 7. Impact of BVJ on school attendance by characteristics.

\begin{tabular}{lcccc}
\hline Variables & Boys & Girls & Youngest & Boys and Youngest \\
\hline All & & & & \\
Treated $* 2009$ & $0.064^{* * *}$ & 0.032 & $0.101^{* *}$ & $0.150^{* * *}$ \\
& $(0.027)$ & $(0.025)$ & $(0.044)$ & $(0.065)$ \\
$\mathrm{N}$ & 2,577 & 2,204 & 1,035 & 569 \\
\hline Urban & & & & \\
Treated $* 2009$ & 0.035 & 0.025 & 0.036 & 0.066 \\
& $(0.033)$ & $(0.030)$ & $(0.053)$ & $(0.085)$ \\
N & 1,673 & 1,520 & 704 & 370 \\
\hline Rural & & & & \\
Treated $* 2009$ & $0.124^{* * *}$ & 0.057 & $0.231^{* * *}$ & $0.300^{* * *}$ \\
& $(0.049)$ & $(0.043)$ & $(0.084)$ & $(0.106)$ \\
N & 904 & 684 & 331 & 199 \\
\hline
\end{tabular}

Notes: Dependent variable is school attendance. Sample includes households among the poorest 20 percent with children aged 15 and 16 years only. Robust standard errors in parentheses. All columns include controls for number of children, education, age and race of head, household composition, urban areas (only for "All" sample), and state dummies. Each column reports the results a different regression. Starred coefficients are significant at the ${ }^{* * *} 1$ percent, ${ }^{* *} 5$ percent, and ${ }^{*} 10$ percent levels. 
Table 8. Impact of BVJ on time allocation by children characteristics.

\begin{tabular}{lcccc}
\hline Variables & Boys & Girls & Youngest & Boys and Youngest \\
\hline \multirow{2}{*}{ Not Studying nor Working } & -0.052 & -0.021 & -0.030 & -0.020 \\
& $(0.039)$ & $(0.029)$ & $(0.055)$ & $(0.078)$ \\
Studying Only & -0.003 & 0.003 & -0.108 & -0.231 \\
& $(0.024)$ & $(0.012)$ & $(0.095)$ & $(0.151)$ \\
Working Only & 0.025 & -0.033 & 0.077 & 0.126 \\
& $(0.040)$ & $(0.036)$ & $(0.078)$ & $(0.100)$ \\
Studying and Working & 0.030 & $0.050^{* *}$ & 0.061 & $0.125^{* * *}$ \\
& $(0.035)$ & $(0.023)$ & $(0.039)$ & $(0.052)$ \\
$\mathrm{N}$ & 2,577 & 2,204 & 1,035 & 569 \\
\hline
\end{tabular}

Notes: The dependent variable is time allocation (the four options in the first column). Sample includes households among the poorest 20 percent with children aged 15 and 16 years only. Robust standard errors in parentheses. Entries are marginal effects of each variable on the predicted probability of each option. Columns report results of a single (multinomial logit) regression and include controls for number of children, education, age and race of head, household composition, urban areas (only the "All" sample), and state dummies. Starred coefficients are significant at the ${ }^{* * *} 1$ percent, ${ }^{* *} 5$ percent, and ${ }^{*} 10$ percent levels.

\subsection{Impact on parents}

In addition to analyzing the direct impact that granting the BVJ may have on young people, it is important to carefully examine how the program impacts the family's time allocation, in particular the time allocated to the labor market. To verify whether there is a disincentive for other beneficiary household members to work, the so-called "laziness effect", the impact of the BVJ on the labor supply of fathers and mothers was assessed both in terms of their participation in the labor market and the number of hours worked.

We first investigate the effects of the BVJ on the probability of working and then on hours worked, for both mothers and fathers in the treatment group. The DID model has the same form as described in equation (3) for youngsters. We used the same controls as before, with the difference that the dummy for households with only a father was omitted in the regressions of mothers, and the dummy for households with only a mother was omitted for the regressions of fathers.

It can be observed from Table 9 that there was not a statistically significant change in the behavior of mothers or fathers in the overall sample regarding either their labor force participation or the number of working hours. This is also valid for the urban sample and for fathers in the rural area but the impact estimates are positive and statistically significant for mothers in rural families. It is possible that this increase in mothers' labor supply occurred to compensate for the reduction in household income due to the youngsters' reduced labor supply. Another plausible explanation is that because young people are now spending more time in school, their mothers have more free time and, consequently, could increase their labor supply.

It is interesting to note that the results in Table 9 suggest that the BVJ has not triggered the so-called "laziness effect", i.e., stimulated a reduction in labor supply of adults. This contention is in line with the bulk of the CCT literature for Brazil and other countries (see section 3.2).

\subsection{Regional differences}

We also checked whether the program's effects were different across the geographical regions of Brazil. This may be important because the Brazilian regions are quite heterogeneous in many cultural and social development aspects. According to the MDS data, the spatial distribution of the PBF's transfers is 
Table 9. Impact of the BVJ on parental time allocation.

\begin{tabular}{|c|c|c|c|c|}
\hline \multirow[b]{2}{*}{ Variables } & \multicolumn{2}{|c|}{ Mothers } & \multicolumn{2}{|c|}{ Fathers } \\
\hline & $\begin{array}{l}\text { Probability } \\
\text { of work } \\
\text { (1) }\end{array}$ & $\begin{array}{l}\text { Working } \\
\text { hours } \\
(2)\end{array}$ & $\begin{array}{l}\text { Probability } \\
\text { of work } \\
\text { (3) }\end{array}$ & $\begin{array}{c}\text { Working } \\
\text { hours } \\
(4)\end{array}$ \\
\hline \multicolumn{5}{|l|}{ All } \\
\hline Treated $* 2009$ & $\begin{array}{c}0.036 \\
(0.027)\end{array}$ & $\begin{array}{r}1.852 \\
-1.276\end{array}$ & $\begin{array}{c}0.016 \\
(0.018)\end{array}$ & $\begin{array}{r}-0.0005 \\
(0.930)\end{array}$ \\
\hline Observations & 4,620 & 2,405 & 3,622 & 3,015 \\
\hline \multicolumn{5}{|l|}{ Urban } \\
\hline Treated $* 2009$ & $\begin{array}{c}0.019 \\
(0.035)\end{array}$ & $\begin{array}{r}0.685 \\
-1.860\end{array}$ & $\begin{array}{c}0.017 \\
(0.027)\end{array}$ & $\begin{array}{l}-0.304 \\
-1.271\end{array}$ \\
\hline Observations & 3,090 & 1,341 & 2,194 & 1,674 \\
\hline \multicolumn{5}{|l|}{ Rural } \\
\hline Treated $* 2009$ & $\begin{array}{c}0.092^{* *} \\
(0.044)\end{array}$ & $\begin{array}{c}4.034^{* * *} \\
-1.683\end{array}$ & $\begin{array}{c}0.017 \\
(0.018)\end{array}$ & $\begin{array}{r}0.444 \\
-1.377\end{array}$ \\
\hline Observations & 1,530 & 1,064 & 1,428 & 1,341 \\
\hline
\end{tabular}

Notes: Dependent variable is a binary indicator for work (columns (1) and (3)) and a continuous variable for hours of work (columns (2) and (4)). Sample includes households among the poorest 20 percent with children aged 15 and 16 years only. Robust standard errors in parentheses. All columns include controls for number of children, education, age and race of head, household composition, urban areas (only for the "all" sample), and state dummies. Each column reports the results of a different regression. Starred coefficients are significant at the ${ }^{* * *} 1$ percent, ${ }^{* *} 5$ percent, and ${ }^{*} 10$ percent levels.

highly uneven across regions of the country. Indeed, the main destination of program resources is the Northeast region (53.2 percent), followed by the Southeast region (23.4 percent). Far from representing a failure in the distribution of resources, this is a result of the program's objective to reduce poverty levels in the country: according to the MDS, almost three quarters of poor families in Brazil in 2006 were concentrated in these two regions.

The impact of the expansion of the PBF on the school enrollment of youths by region is shown in Table 10. The results evince that the granting of the new benefit only had a significant impact in the Northeast and Southeast regions. The probability of attending school for our group of interest in these regions increased by respectively 7.6 and 9.3 percentage points after the expansion of the Bolsa Familia program in 2007. Looking at the results for the urban/rural stratification within the regions, we see that the effect for the Northeast is positive for the two strata and higher for rural youths in this region. The effect for the Southeast is only statistically significant in its urban area and there appears a weakly significant impact for the rural area in the South region.

\subsection{A Placebo test}

To test the robustness of the results, we estimated the same school enrollment model using samples from a previous time period. Again, the treatment group was composed by households among the poorest 20 percent with 16-year-olds youths as members. The control group included 15-year-olds and they were also among the poorest 20 percent. For this exercise, the years 2003 to 2006 were used, which are periods prior to the creation of the BVJ. This is a placebo test, in which 2006 was defined as the posttreatment year. Thus, we substituted the dummy variable for the post-program in equation (3), making 
Table 10. Impact of the BVJ on school attendance by region.

\begin{tabular}{|c|c|c|c|c|c|}
\hline Variables & Midwest & Northeast & North & Southeast & South \\
\hline \multicolumn{6}{|l|}{ All } \\
\hline Treated $* 2009$ & $\begin{array}{c}-0.017 \\
(0.076)\end{array}$ & $\begin{array}{l}0.076^{* * *} \\
(0.025)\end{array}$ & $\begin{array}{c}-0.004 \\
(0.047)\end{array}$ & $\begin{array}{l}0.093^{* *} \\
(0.045)\end{array}$ & $\begin{array}{c}-0.032 \\
(0.078)\end{array}$ \\
\hline Observations & 306 & 2,523 & 770 & 820 & 362 \\
\hline \multicolumn{6}{|l|}{ Urban } \\
\hline Treated $* 2009$ & $\begin{array}{c}-0.036 \\
(0.088)\end{array}$ & $\begin{array}{c}0.063^{* *} \\
(0.032)\end{array}$ & $\begin{array}{c}-0.010 \\
(0.058)\end{array}$ & $\begin{array}{c}0.093^{*} \\
(0.048)\end{array}$ & $\begin{array}{r}-0.137 \\
(0.093)\end{array}$ \\
\hline Observations & 240 & 1,551 & 491 & 647 & 264 \\
\hline \multicolumn{6}{|l|}{ Rural } \\
\hline Treated $* 2009$ & $\begin{array}{c}-0.028 \\
(0.148)\end{array}$ & $\begin{array}{l}0.100^{\text {*** }} \\
(0.040)\end{array}$ & $\begin{array}{c}-0.012 \\
(0.085)\end{array}$ & $\begin{array}{c}0.071 \\
(0.114)\end{array}$ & $\begin{array}{c}0.259^{*} \\
(0.142)\end{array}$ \\
\hline Observations & 66 & 972 & 279 & 173 & 98 \\
\hline Controls & Yes & Yes & Yes & Yes & Yes \\
\hline $\begin{array}{l}\text { Notes: Dependent v } v \\
\text { children aged } 15 \text { an } \\
\text { of children, educati } \\
\text { state dummies. Ea } \\
\text { significant at the * }\end{array}$ & icent, ${ }^{* *} 5$ & ce. Sample & $\begin{array}{l}\text { des househ } \\
\text { arentheses. }\end{array}$ & nong the $p c$ & $\begin{array}{l}20 \text { percent } \\
\text { trols for num } \\
\text { ll" sample), }\end{array}$ \\
\hline
\end{tabular}

it now equal to 0 when the year is 2003 , and equal to 1 when the year is 2006 .

Table 11 shows that the interaction between the (pseudo) indicator of treatment and time did not attract a significant coefficient for this sample, irrespective of whether the control variables were included or not in the regression. This shows that our estimated effects do not seem the result of a statistical artifact. The same robustness test was then applied to verify the effects on young people's time allocation (results not shown) and there were no statistically significant effects either, strengthening the causal interpretation of the results found in this study.

\section{FINAL CONSIDERATIONS}

The objective of this study was to evaluate the impact of the expansion of the PBF, which occurred in 2007 with the creation of the BVJ, on the time allocation of the beneficiary household members. The establishment of this new type of benefit sought to help poor young people aged between 16 and 17 to stay in school because there is an increase in the dropout rate in this age group.

The effects of the benefit were investigated with regard to the school enrollment of beneficiary youths and also to their time allocation decisions in terms of working and studying activities. We further investigate the effects of the expansion of the PBF on potential behavioral changes of their fathers and mothers with respect to participation in the workforce and working hours. The data used were taken from PNAD, the main household survey in the country, and the analysis covered the years 2006, before the creation of the benefit, and 2009, following the introduction of the BVJ.

Regarding the program's effects on school enrollment, the results showed that the creation of the BVJ had a positive impact (1 pp) on the probability that 16-year-olds from poor families stay in school. The results show that the impact seems to be absent in urban areas but it is quite high for youths living in rural areas (1 pp). When separating the sample by the regions of Brazil, positive effects were found on young people's school enrollment especially in the Northeast (in both urban and rural areas) and 
Table 11. Placebo - Impact on school attendance - 2003-2006.

\begin{tabular}{lcc}
\hline Variables & $\begin{array}{c}\text { Without Controls } \\
(1)\end{array}$ & $\begin{array}{c}\text { With Controls } \\
(2)\end{array}$ \\
\hline Treated & $-0.063^{* * *}$ & $-0.061^{* * *}$ \\
& $(0.015)$ & $(0.015)$ \\
2006 & 0.001 & -0.013 \\
& $(0.013)$ & $(0.015)$ \\
Treated ${ }^{*} 2006$ & -0.014 & -0.008 \\
& $(0.021)$ & $(0.021)$ \\
Constant & $0.885^{* * *}$ & $0.829^{* * *}$ \\
& $(0.010)$ & $(0.067)$ \\
\hline Observations & 4,601 & 4,601 \\
R-squared & 0.010 & 0.043 \\
\hline
\end{tabular}

Notes: Dependent variable is school attendance. Sample includes households among the poorest 20 percent with children aged 15 and 16 years in 2003 and 2006 only. Robust standard errors in parentheses. Column (2) includes controls for number of children, education, age and race of head, household composition, urban areas, and state dummies. Each column reports the results a regression using a different sample. Starred coefficients are significant at the ${ }^{* * *} 1$ percent, ${ }^{* *} 5$ percent, and * 10 percent levels.

in the Southeast (only in the urban area). Moreover, the effects on school enrollment were greater for young males and for individuals who were the youngest child (especially if it was a boy) in the household. This last result suggests that the conditionality of the program is binding: if the youngest child is not enrolled in school families fear they may lose the program benefit altogether. The same pattern was detected for rural families but again no effect was found for the urban area.

Additional exercises showed that the effects of increasing school enrollment occurred mainly through the rise in the probability of being simultaneously engaged in studying and working activities. The marginal effects indicated that the probability of choosing to study and work for young people in the treatment group increased approximately $1 \mathrm{pp}$.

The econometric results also showed that the program hardly impacted the parents' labor supply decisions. Indeed, the results showed that neither the labor market participation nor the working hours of parents were negatively affected by the BVJ. These results confirm what has been previously found in the literature on the absence of a "laziness effect" of CCT programs.

As a whole, the results show that the creation of the BVJ seems to have accomplished its main goal, which was to increase school attendance and thus the accumulation of human capital among poorer young people, thereby reducing the intergenerational transmission of poverty. The magnitude of the impact is substantial, as it allows to bridge over $30 \%$ of the gap in the rates of school enrollment at age 16 between household in the top and bottom deciles of the income distribution.

The rural area and the Northeast region display the highest (extreme) poverty rates as well as the lowest enrollment rates for youngsters in Brazil. As the PBF is a well targeted intervention, it is not surprising the BVJ showed the highest impacts in these segments of the country. At the same time, the seemingly absence of impacts in the other segments (especially the urban area) suggests that the BVJ does not seem to be well designed to improve the school enrollment rates of adolescents in the relatively more developed areas of the country. For instance, it could be that that increasing school enrollment 
The Impact of the Expansion of the Bolsa Família Program

youths in urban areas through a CCT program requires payment of higher benefits. But this type of discussion calls for a carefully conducted cost-benefit analysis, which is beyond the scope of this study.

\section{REFERENCES}

Ahmed, A. U., Adato, M., Kudat, A., Gilligan, D., Roopnaraine, T., \& Colasan, R. (2007, March). Impact evaluation of the conditional cash transfer program in Turkey: Final report (Report). Washington, DC: International Food Policy Research Institute (IFPRI) - AGRIN Co. Ltd. Retrieved from http://dare.uva.nl/document/166078

Alzúa, M. L., Cruces, G., \& Ripani, L. (2010, March). Welfare programs and labor supply in developing countries: Experimental evidence from Latin America (Documento de Trabajo No. 95). La Plata: Centro de Estudios Distributivos, Laborales y Sociales (CEDLAS). Retrieved from http://cedlas.econo.unlp.edu.ar/archivos_upload/ doc_cedlas95.pdf

Attanasio, O., Fitzsimons, E., \& Gomez, A. (2005, March). The impact of a conditional education subsidy on school enrolment in Colombia (Report Summary Familias No. 01). London: Institute for Fiscal Studies - Centre for the Evaluation of Development Policies. Retrieved from http://www.ifs.org.uk/publications/3329

Attanasio, O., Meguir, C., \& Santiago, A. (2012). Education choices in Mexico: Using a structural model and a randomized experiment to evaluate PROGRESA. The Review of Economic Studies, 79(1), 37-66. doi: 10.1093/restud/rdr015

Behrman, J. R., Gallardo-García, J., Parker, S. W., Todd, P. E., \& Vélez-Grajales, V. (2012). Are conditional cash transfers effective in urban areas? Evidence from Mexico. Education Economics, 20(3), 233-259. doi: $10.1080 / 09645292.2012 .672792$

Bourguignon, F., Ferreira, F. H. G., \& Leite, P. G. (2003). Conditional cash transfers, schooling, and child labor: Micro-simulating Brazil's Bolsa Escola program. World Bank Economic Review, 17(2), 229-254. doi: 10.1093/wber/lhg018

Brollo, F., La Ferrara, E., \& Kaufmann, K. (2013). Learning about the enforcement of conditional welfare programs: Evidence from the Bolsa Familia program in Brazil [mimeo].

Brollo, F., La Ferrara, E., \& Kaufmann, K. (2015). The political economy of enforcing conditional welfare programs: Evidence from Brazil [mimeo].

Costanzi, R. N., Souza, F. L. d., \& Ribeiro, H. V. M. (2010). Efeitos do programa bolsa família no acesso à educação entre os mais pobres. Boletim Informações Fipe, 360, 28-32. Retrieved from http://downloads.fipe.org.br/ publicacoes/bif/2010/9_bif360.pdf

De Janvry, A., Finan, F., \& Sadoulet, E. (2007). Local governance and efficiency of conditional cash transfer programs: Bolsa Escola in Brazil [Technical Report]. Department of Agricultural and Resource Economics.

Edmonds, E. V., \& Schady, N. (2009, September). Poverty alleviation and child labor (Working Paper No. 15345). National Bureau of Economic Research (NBER). doi: 10.3386/w15345

Ferro, A. R., \& Nicolella, A. C. (2007). The impact of conditional cash transfer programs on household work decisions in Brazil [mimeo].

Fiszbein, A., Schady, N., Ferreira, F. H. G., Grosh, M., Keleher, N., Olinto, P., \& Skoufias, E. (2009). Conditional cash transfers: Reducing present and future poverty (World Bank policy research report No. 47603). Washington, DC: World Bank. Retrieved from http://documents.worldbank.org/curated/en/2009/01/10298306/conditional -cash-transfers-reducing-present-future-poverty

Foguel, M. N., \& Barros, R. P. d. (2010). The effects of conditional cash transfer programmes on adult labour supply: An empirical analysis using a time-series-cross-section sample of Brazilian municipalities. Estudos Econômicos, 40(2), 259-293. doi: 10.1590/S0101-41612010000200001

Glewwe, P., \& Kassouf, A. L. (2012). The impact of the Bolsa Escola/Familia conditional cash transfer program on enrollment, dropout rates and grade promotion in Brazil. Journal of Development Economics, 97(2), 
505-517. doi: 10.1016/j.jdeveco.2011.05.008

Khandker, S., Pitt, M., \& Fuwa, N. (2003). Subsidy to promote girls secondary education: The female stipend program in Bangladesh. (unpublished manuscript)

Medeiros, M., Britto, T., \& Soares, F. (2007, June). Programas focalizados de transferência de renda no Brasil: Contribuições para o debate (Texto para Discussão No. 1283). Brasília,DF: Instituto de Pesquisa Econômica Aplicada (IPEA). Retrieved from http://www.ipea.gov.br/portal/images/stories/PDFs/TDs/td_1283.pdf

Parker, S., \& Skoufias, E. (2000, October). The impact of PROGRESA on work, leisure, and time allocation (Final Report). Washington, DC: International Food Policy Research Institute (IFPRI). Retrieved from http://ebrary .ifpri.org/cdm/ref/collection/p15738coll2/id/125439

Pedrozo Jr, E. (2010). Efeitos de elegibilidade e condicionalidade do Programa Bolsa Família sobre a alocação de tempo dos membros do domicílio (PhD Thesis, Escola de Economia de São Paulo - Fundação Getulio Vargas, São Paulo, SP). Retrieved from http://hdl.handle.net/10438/8311

Pellegrina, H. S. (2011). Impactos de curto prazo do Programa Bolsa Família sobre o abandono e o desempenho escolar do alunado paulista [Evaluating the impact of programa bolsa familia on dropout rates and performance] (Master's Thesis, Universidade de São Paulo-Faculdade de Economia, Administração e Contabilidade, São Paulo, SP). Retrieved from http://www.teses.usp.br/teses/disponiveis/12/12138/ tde-26092011-165149/pt-br.php

Puhani, P. A. (2012). The treatment effect, the cross difference, and the interaction term in nonlinear "differencein-differences" models. Economics Letters, 115(1), 85-87. doi: 10.1016/j.econlet.2011.11.025

Rubio-Codina, M. (2010). Intra-household time allocation in rural Mexico: Evidence from a randomized experiment. In S. Polachek \& K. Tatsiramos (Eds.), Child labor and the transition between school and work (Vol. 31, pp. 219-257). Emerald. (Book Series: Research in Labor Economics) doi: 10.1108/S0147-9121(2010)0000031011

Schady, N., Araujo, M. C., Peña, X., \& López-Calva, L. F. (2008). Cash transfers, conditions, and school enrollment in Ecuador. Economía, 8(2), 43-77. doi: 10.2307/20065524

Skoufias, E., \& Di Maro, V. (2008). Conditional cash transfers, adult work incentives, and poverty. The Journal of Development Studies, 44(7), 935-960. doi: 10.1080/00220380802150730

Skoufias, E., Parker, S. W., Behrman, J. R., \& Pessino, C. (2001). Conditional cash transfers and their impact on child work and schooling: Evidence from the PROGRESA program in Mexico. Economía, 2(1), 45-96. Retrieved from http://www.jstor.org/stable/20065413

Soares, S., \& Satyro, N. (2009, outubro). O programa Bolsa Família: Desenho institucional, impactos e possibilidades futuras (Texto para Discussão No. 1424). Brasília·DF: Instituto de Pesquisa Econômica Aplicada (IPEA). Retrieved from http://www.ipea.gov.br/portal/index.php?option=com_content\&view= article\&id $=4980$

Tavares, P. A. (2010). Efeito do Programa Bolsa Família sobre a oferta de trabalho das mães. Economia e Sociedade, 19(3), 613-635.

Teixeira, C. G. (2008). Análise do impacto do Programa Bolsa Família na oferta de trabalho dos homens e mulheres. PNUD/IPC. Retrieved from http://www.ipc-undp.org/publications/mds/27P.pdf 